\title{
ĒTIKA KĀ AKUSTISKA DZĪVESMĀKSLA: AUGUSTS MILTS
}

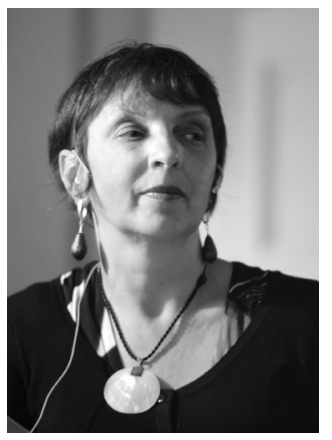

Velga Vēvere, Dr. phil., Latvijas Universitātes Filozofijas un sociologíijas institūta vadošā pētniece, Ekonomikas un kultūras augstskolas profesore, Biznesa augstskolas Turība vieslektore. Pētnieciskās intereses saistītas ar filozofijas vēsturi (fenomenoloǵiju, eksistenciālismu, amerikāṇu pragmatismu), sociālo filozofiju un komunikācijas filozofiju, ētiku (ieskaitot biznesa ētiku). Vairāku dāņu domātājam S. Kirkegoram veltītu monogrāfiju un daudzu zinātnisku rakstu autore.
Raksturvārdi: A. Milts, Z. Baumans, S. Kirkegors, ētika, atmiņa, dzīvesstāsti, publicistika.

\section{Ievads}

Ievērojamais sociologs, ikdienas dzīves, sociālo, kā arī morālo fenomenu aprakstītājs Zigmunds Baumans mūsdienu laikmeta raksturojumam izmanto vārdu salikumu "plūstošā modernitāte" (angl. - liquid modernity), kas apzīmē sociālo attiecību, sociālās dzīves formu nepastāvīgumu, identitāšu mainīgumu. Pēc Z. Baumana domām, mēs kā cilvēki esam pārvērtušies no "svētceḷniekiem" (patības jēgas meklētājiem) par "tūristiem" jeb "nomadiem" (īslaicīgas sociālās pieredzes meklētājiem). Tomēr kādēḷ tieši "plūstošā modernitāte"? Uz šo jautājumu Z. Baumans atbild, izmantojot cieta ķermeņa un šksidruma īpašību pretstatījumu. "Ja cietiem ķermeņiem piemît skaidri izteiktas telpiskas dimensijas, kas noturīgas pret dažādu spēku ietekmēm, tādējādi samazinot laika nozīmi [..] šķidrumi nespēj ilgstoši saglabāt savu formu un allaž atrodas pārmaiņu procesā; tādējādi tiem nozīmīgs ir laika plūdums, nevis to atrašanās vieta: vieta, ko tie ieņem tikai uz "mirklì"'. ${ }^{1}$ Attiecībā uz indivīdu "plūstošā modernitāte" nozīmē nenoteiktības palielināšanos - nepārtrauktu sociālo lomu, pozīciju, orientāciju maiṇu, izvēloties aizvien jaunas mìtnes vietas, amatus, dzīves partnerus, komunikācijas tīklojumus. Ja, no vienas puses, palielinās personiskā atbildība par momentāni, šeit un tagad, pien,emamajiem lēmumiem, tad, no otras puses, lēmumu nomaiņas ātrums liek apšaubīt katras iepriekšējās izvēles morālos kritērijus. "Šis ir morālais aklums - paša izvēlēts, paša sev uzspiests vai fatālistiski pieņemts - laikmetā, kad vairāk nekā jebkad agrāk nepieciešams ātrums informācijas apstrādē un sajūtu apjēgumā. Lai atgūtu redzi šajos tumšajos laikos, ir jāatgūst cilvēciskā cieņa, kā arī priekšstats par cilvēka būtības neizzināmību." ${ }^{2}$ Citiem vārdiem, jāapgūst vai jāatgūst spēja saskatīt tikumiskos orientierus, tādējādi priekšplānā izvirzās ètiskas audzināšanas un audzinātāja personības problemātika.

2018. gada 28. maijā LU notika profesora, dzīvesstāstu pētnieka, daudzu filozofu

\footnotetext{
1 Bauman 2006, 2.

2 Bauman \& Donskis 2013, 11.
} 
paaudžu skolotāja, apgaismotāja šī vārda visplašākajā nozīmē Augusta Milta (1928-2008) 90 gadu atcerei veltita konference / pieminas sarīkojums Augusts Milts - par dzīvi, ètiku un dzīvesstāstiem, kurā piedalījās profesora kolēǵi, skolnieki un sekotāji. Lai arī nevar runāt par A. Milta ētikas skolu š̄ vārda tiešā nozīmē, gandrīz katrs ētikas skolotājs, pasniedzējs ir vina izaudzināts (Vēstures un filozofijas fakultātē) vai vismaz ietekmēts. Iespējams, ka vienas ètikas skolas Latvijā neesamību nosaka mūsdienu laikmeta specifika - specializācija (komunikācijas ētika, mediju ētika, biznesa ētika, bioētika, medicīnas ètika, zinātnes ètika utt.), sazarošanās (iekḷaušanās dažādās filozofiskās tradīcijās - fenomenoloǵijā, hermeneitikā, eksistenciālismā, dzīves filozofijā, pragmatismā, neotomismā, aksiologijīâ, feminismā utt.). Taču jāatzīst, ka ētikas jautājumi tiek skarti dažādās publikācijas (monogrāfijās, rakstos) - filozofisku tēmu izvērsumos. Te var minēt tādus autorus kā Skaidrīte Lasmane, Andris Rubenis, Māra Rubene, Elga Freiberga, Ieva Lapinska, Maija Kūle, Vija Sīle, Vents Sîlis, Ivars Neiders un daudzus citus. Šì raksta pamatā ir konferencē nolasītais referāts. Rakstā iezīmēti divi tematiskie lauki: laika un autobiogrāfiskie motīvi - attieksme pret paša dz̄̄vi un tekstiem, kā arī ètikas kā dzīvesmākslas izpausmes ikdienā un pedagoǵiskajā darbībā.

\section{Biogrāfiskā bezgalība}

Atmiņas problemātikai ir īpaša loma Milta radošajā dzīvē - gan atmiņām par paša bērnību un dzīvi, gan kolektīvajai atminai, kuras izpausmes rodamas dzīvesstāstos. Viņš raksta: "Atskats pagātnē ir sava veida dzīves filozofija, kas dod vispārinājumu un būtiskā apjēgsmi. Dīvaini, bet ikdienas liecinieces - dienasgrāmatas - atgādinātie daudzie notikumi šķiet neticami. Atmiņas vispārinājumiem ir vairāk izteikta idealizācija, ko pastiprina arī bērnības un jaunības vitalitāte. Vecums, profesionālā orientācija, karjeras veiksme vai neveiksme un īpaši laikmeta kardinālās pārmaiņas jau arī ievērojami pārvērtē notikumus." "3 Atmiņas (gan individuālās, gan kolektīvās) specifika ir tajā, ka retrospektīvā skatījumā mainās

3 Milts 2008a, 10. notikumu interpretācija vai, vēl vairāk, notikumi var sakārtoties (un tas lielākoties arī notiek) nehronologiskā secībā, centrējoties ap zīmīgiem faktiem/notikumiem/datumiem. Visspilgtāk, iespējams, tas izpaužas tieši dz̄̄vesstāstu vēstījumos, kur centrālais notikums un attieksme pret to nosaka gan vēstījuma formu, gan satura izkārtojumu (notikumu secību), gan vēstījuma intonāciju. Tādēḷ gluži loǵiska škiet viṇa iesaistīšanās mutvārdu vēstures pētījumos, kur uzmanības centrā ir individuālās un sociālās atmiņas krustpunkti un kur pētnieka darbs līdzinās rūpīgam arheologa darbam laikmeta uzslāņojumu noņemšanai, lai atrastu būtisko, kopīgo. Runājot par dzīves stāstiem kā tautas ilglaicīgo atminu, A. Milts raksta: "Nepārtraukti sekojot ikdienas aktualitātēm, taču nepadarot aktuālu arī pagātni, ilglaicīgo atmiņu, cilvēks sadrumstalojas, nespēj veidot dz̄ives mozaīku, iegūt stabilitāti. Ilglaicīgā atmiņa, dzīves stratēgiskais skatījums ir sirdsapziņas, dzīves jēgas un stabilu pamatu pastāvēšanas nosacījums gan cilvēkā, gan tautā. Mutvārdu vēsture, cilvēku dzìvesstāstu pētīšana ḷauj paildzināt tautas atmiņu, pietuvoties to pamatvērtību atklāsmei, bez kurām garīgā dzīve degradējas." ${ }^{4}$ Šāda ilglaicīgā vēsturiskā (sociālā) atmiņa ietekmē tagadnes parādību interpretāciju, cilvēka izpratni par savu novietojumu sociālajā un kultūras vidē, kā arī attieksmi pret izdzīvoto pagātni un izdzīvojamo nākotni. Mutvārdu vēstures akadēmiskie pētījumi, pēc A. Milta domām, ir nepieciešami vairāku iemeslu dēḷ: pirmkārt, mutvārdu vēstījumos atklājas tā sauktās tabu tēmas, kuras var neietilpt oficiālajā vēstures diskursā (alternatīvi skatījumi, noklusējumi utt.); otrkārt, mutvārdu vēsture ir ikdieniško (mums līdzīgo vai no mums atškirīīgo, bet tomēr mums tuvo) cilvēku vēsture; treškārt, tā ir cilvēku pārdzīvojumu vēsture, laikmeta emocionālais kartējums; ceturtkārt, pētniecības procesā cilvēks ir gan pētniecības objekts, gan pētniecības subjekts, jo vēstījuma procesā izzina pats sevi; piektkārt, cilvēka dzīvesstāsts ietver sevī attiecības ar daudziem cilvēkiem, gimeni, tautu, vēsturiskiem notikumiem, tādējādi tie var kalpot kā informācijas avots vēsturei, psiholog̣ijai, sociālajām zinātnēm utt.; sestkārt,

4 Milts 2001, 34. 
mutvārdu vēstījumi allaž ir saistīti ar atbildību par pagātni, gan savējo, gan savu priekšteču (jo īpaši aktuāli tas skan pašlaik, kad notiek diskusijas, saistītas ar čekas maisu atvēršanu); septītkārt, dzīvesstāstu uzklausīšana ir vienlaikus pētnieka ieklausīšanās pašam sevī, sevis iepazī̌šana, iepriekšêjās pieredzes un skatījuma uz faktiem un notikumiem pārvērtēšana; astotkārt, mutvārdu vēstures pētniecība l,auj apjēgt savas un citu tautu mentalitāti, kultūru pārklāšanās laukus, kas veicina toleranci pret citādību un citādo. ${ }^{5}$ Blakus tam dzīvesstāstos svarīga vēstījuma forma - balss, žests, intonācija, pauze, kustība, zemteksts, simbolika kā kultūras fenomens. ${ }^{6}$

Interesanti tas, ka daudz kas no iepriekš teiktā (nosacīti to var dēvēt par dzīvesstāstu stratēgiijām) tiek izmantots paša autora biogrāfijas un tekstu retrospektīvā uzlūkojumā.

Grāmatā Saskarsmes ètika A. Milts saka: "Biogrāfiju mēdz attēlot ar bezgalības zīmi, kurā vienota pagātne, tagadne un nākotne. [..] Cilvēku dzīve ir neizsmeḷama gan saskarsmes bagātībā, gan ietekmju daudzveidībā, gan apstākḷu neizmērojamībā, gan nākotnes nodomos, kur fantāzija savijas ar reālām iespējām. Cilvēka izpētē mums vienmēr jāiekḷauj "x faktors", nezināmais. Mēs īsti nespējam atšifrēt cilvēka darbības motīvus, bezapzinu. Ne tikai citi, bet arī cilvēks pats sev ir vairāk vai mazāk mīkla. Pārsteidzoši, ka tas, kas ir vistuvākais saskarsmē, dažkārt ir tālākais izziṇā." " Š̄̄s mīklas atminēšanai dota vai visa dzīve, taču paradoksālā kārtā - šķietami atminētais, atcerētais, fiksētais rada aizvien jaunus jautājumus par sevi pasaulē (atbildību attiecībā pret citiem) un pasauli sevī (atbildību attiecībā pret pašu). "Atskats pagātnē ir arī atbildība pret senčiem, tuviem un tāliem cilvēkiem, atbild̄̄ba par savstarpējām attiecībām, kas bijušas tālu no pilnības, atbildība par nodzīvoto laiku..."8 Biogrāfija atvērta tik ilgi, kamēr cilvēks spēj kritiski atskatīties uz savu dzīvi un veikumu.

\footnotetext{
5 Milts 2001.

Milts 1996.

Milts 2004, 39.

8 Milts 2008a, 21.
}

\section{Teksts un balss}

Deviņpadsmitā gadsimta dāṇu filozofs un teologs Sērens Kirkegors savu darbu, kas veltīts atkārtošanās/atkārtojuma problēmai ${ }^{9}$, iesāk ar stāstu par sengrieḳu domātāja Diogena strīdu ar eleātiem. Eleāti, kā zināms, noliedza kustību; lai pierādītu šñ ieskata aplamību, Diogens nevis iesaistījās klātienes vai neklātienes diskusijā, liekot lietā meistarīgi konstruētus argumentus, retoriskas figūras, pārliecinošus (vai ne tik pārliecinošus) pierādījumus racionālu konstruktu formā, nevis ironiskus izteikumus, trāpīgas metaforas, bet gan vienkārši vairākkārt šḳērsoja istabu. Kustības pierādījums ar kustības palīdzību. Lai arī autoram (S. Kirkegoram) šis piemērs kalpo kā ievadījums sarunai par atkārtošanos kā laika noteiksmi un, kas vēl būtiskāk, - kā īpašu eksistences un domāšanas par pasauli veidu, kam raksturīga īpašas ētiskās atbildības uzṇemšanās gan sabiedrības, gan sevis paša priekšā par teikto (tekstu) un neteikto (izdzīvoto). Šādi tulkots atkārtošanās jēgums var kalpot gan Kirkegora filozofiski ētiskās pozīcijas raksturojumam, gan arī kā - plašākā nozīmē - viens no iespējamiem (citu starpā) dzīvesmākslas definējumiem: atkārtoties nozīmē spēt piedzīvot vispirms sevi, tad citu sevī un, visbeidzot, - sevi un citu pasaulē aizvien no jauna. Kustîba, žests, vārds, izteiksme, paradokss, noklusējumi, kas vieš nepateiktā un arī neizteicamā jausmas, tiecas modināt lasītāja subjektivitāti un pašrefleksiju, kamēr teksts iegaismo jābūtības, tikumiskā un/vai reliǵiskā pienākuma problemātiku. Dzīvesmākslas ētika ar savu virzību uz šeit-un-tagad-esamību (praksi) un pārsituatīvā êtikas māksla (teorija) ir vienlīdz nozīmīgi, savstarpēji papildinoši vērsumi indivīda un sabiedrības (gimenes, dzimtas, tautas, nācijas, cilvēces) dzīvē. Tomēr katrā no tiem priekšplānā izvirzās citi akcenti, liekot domāt par neizbēgamo ētikas speciālista dilemmu: satvert netveramo, teorētiski aprakstīt un kategorizēt dzīves vērtībaspektus. Taču visgrūtākais varbūt ir pašam kḷūt par ètikas skolotāju š̄i vārda visplašākajā, humānistiskajā audzinātāja nozīmēe, lekcijās, literārajās esejās, publicistiskajos apcerējumos demonstrējot

9 Kierkegaard 1983, 131. 
ētiku kā īpašu, pašatbildīgu domāšanas/runāšanas/rakstǐšanas jeb, citiem vārdiem, būšanas pasaulē un sabiedrībā mākslu. "Morāle pacel augstāk skatu, bieži veido citādu attieksmi pret dzīves faktiem, pret to interpretāciju. Faktu patiesību paceḷot jēgas patiesībā, morāle rada priekšnoteikumus gara atmodai, atdzimšanai, paverot ceḷu uz templi, uz grēksūdzi, uz dziḷu vēstures un paša dzīves apjēgumu."

Šķiet, ka tieši A. Milta gadījumā runātais, rakstītais un izdzīvotais, pārdzīvotais un piedzīvotais ir tik grodi savijies, ka katrā tekstā (eseju krājumos, intervijās, aforismos, mācību grāmatās, apcerēs, publicētajās lekcijās un vienkārši dzīves vērojumos) ir nepārprotami jūtama viņa klātbūtne, ko nevar atcelt nedz attālums, nedz laiks. Un šì klātbūtne nav kas nemainīgs vai konstants, A. Milts mūs allaž uzrunā no jauna un citādi - varbūt tāpēc, ka paši esam mainījušies no iepriekšējās pārlasīšanas reizes, bet varbūt pats teksts, gluži kā autors, ir īpašs, klasifikācijas mēgeinājumiem nel̦āvīgs. Taču rodas jautājums par to, kā satvert tekstu, nezaudējot autora klātbūtnes iespaidu? Vai atkal, gluži pretēji, kā nepazaudēt tekstu, ļaujoties autora personības nobūrumam? Vai pievērsties biogrāfiskajam, tematiskajam, žanriskajam, tematiskajam, pedagogiskajam aspektam? Bet tiklab iespējams, ka būtiskais, jēgpilnais var iegaismoties uzrakstītā un ieklausītā, teksta un balss, vizuālā un akustiskā sastatījumā, ko nosacīti varētu dēvēt par sadzirdēšanu (uzklausīšanu, ieklausīšanos un, jā, arī reizumis pārklausīšanos) pretstatā salasīšanai (kaut kā iepriekš gatava savākšanai, kolekcionēšanai, uzkrāšanai) jeb varbūt, loti vienkārši, - par katra rakstītā teksta pārvēršanos savdabīgā akustiskā priekšnesumā aktīiā mijiedarbē ar lasītāju kā klausītāju. Šādā situācijā īpaši nozīmīgu lomu spēlē iespējamās saprašanas lauks, kas atrodas kaut kur starp saredzamo un saklausāmo, tātad starp tekstu un balsi. Šì reizumis ne tik viegli apjaušamā starpzona vienlaikus ir arī mūsu pašu unikālās pašizpausmes un pašizziņas lauks, jo autora balss še nav dominējoša, gribu un rīcībspēju paralizējoša, bet gan, gluži pretēji, ir individuālo atbildību rosinoša. A. Milts atzīst: "Morāle ir sava veida dzīves māksla, un tā ir sarežgīitākā

${ }^{10}$ Milts 2004, 23. un radošākā no visām mākslām. Morāle ir viena no radošākajām lietām, kad jālemj, kā izturēt, kā būt labam pret cilvēku noteiktā situācijā, kad iespējami visdažādākie varianti."11 Rakstīto tekstu uzlūkojot, priekšplānā izvirzās teksta un balss attiecības, bet runātajā tekstā (lekcijās, priekšlasījumos, sarunās) spēlē intonācija, ritms, žests. "Ētiskums runā neattiecas tikai uz vārdu un tekstu, bet gan uz visu personību. Nereti galvenais nav pats vārds un teksts, bet intonācija, kas slēpjas aiz teksta. Tā pauž cilvēka dvēseles bagātību, pārdzīvojumu un motivāciju."12 Kā pateikt to, kas svarīgs klausītājam, viṇu neaizvainojot, neuzspiežot savu viedokli kā vienīgo patieso? Daudzi profesora studenti, viņa lekciju klausītāji noteikti atceras profesora īpašo runas manieri - nopietnu un vienlaikus ironisku, pieklusinātu un vienlaikus aizraujošu. Humoram, smiekliem ir īpaša loma socializācijā, izglītošanā, audzināšanā un kultūrā, tomēr tādiem smiekliem, kas nesagrauj cilvēka morālās psiholog̣iskās aizsardzības barjeras.

Noteikti jāmin A. Milta ironija un pašironija, kas visspilgtāk izpaužas viņa filozofiskajā īsprozā un prātulās. Jāpiekrīt E. Bucenieces secinājumam, ka "Augusta Milta esejistiskajā prozā ir pulsējusi šāda urdoša, nedogmatiska, vaicājoša ievirze". ${ }^{13}$ Ironija iezīmē atsvešinājumu, kas ḷauj lasītājam/klausītājam distancēties no teksta/runātāja un pievērsties sev. "Smiekli atkailina, atsedz patiesību bez maskas, etiķetēm."14

\section{Noslēgums}

Kā mācīt ētiku? Kā vēsturi? Kā teorētisku konceptu izvērsumu? Kā savas bijušās, esošās un nākotnes pieredzes izvērtējumu noteiktu domāšanas modeḷu ietvaros? Uz šiem jautājumiem A. Milts atbild: "Ētika interesējas par cilvēkam atvēlētā laika piepildījuma jēgu. Ar to cieši saistîta ir sirdsapziņa, kas laika mūžības izjūtu vieno ar dzīves situācijām." ${ }^{15} \mathrm{Ka}$ mācīt biznesa ētiku? Kā universālu noteikumu

\footnotetext{
11 Beitnere 2008, 77.

12 Milts 2004, 51.

13 Buceniece 2008, 259.

14 Milts 2004, 104.

15 Milts 2008b, 24.
} 
kopumu vai kā atsevišķu gadījumu analīzi? Vai abējādi? Vairums A. Milta ētikas problemātikai veltīto tekstu ir ar spēcīgi izteiktu pedagoǵisko intenci - lekcijas, mācību grāmatas, didaktiskas esejas, kas kalpo kā izziņas avots ètikas (tajā skaitā profesionālās êtikas) pasniedzējiem vidusskolās un augstskolās mūsdienās, tomēr, šksiet, būtiskākais, ko esam mantojuši no A. Milta, ir ētikas kā dz̄̄vesmākslas mērkisis, kas izpaužas kā klātesamības praktizēšana vispirms būt klāt pašam sev kā pasniedzējam (profesionālisms, savu robežu un ietekmes uz citiem apzināšanās), studentiem būt klātesošiem savā dzīvē, spējot kritiski skatīt savu ikdienas rīcību, nel̦aujoties mirkḷa tirānijai, būt atbildīgiem - ekoloǵiski, ekonomiski, sociāli, cilvēciski. Vai iespējams cilvēkus iemācīt dz̄̄vot un rīkoties pareizi? Protams, nē, tas arī nav pasniedzēja uzdevums, drīzāk tas ir - radīt saprašanās (dialoga) lauku, iespēju sarunāties pat pilnīgas viedokḷu nesakritības gadījumā. Kā biznesā domāt vairākus soḷus uz priekšu, lai šīsdienas lēmums neapdraudētu mūs pašus, mūsu līdzcilvēkus rīt vai parìt? Intervijā žurnālam Karogs viņš atzīst: "Bieži vien uzskata tā, ka, ja nu ētikas pasniedzējs, tad pašai tai personībai kā tādai ir jābūt ārkārtīgi êtiskai. Jo vispār paraugi morālē - tā ir l̦oti riskanta problēma. Loti riskanta problēma. Jo morāle jau lielā mērā ir arī jābūtības problēma. Un pastāv mūžīgais morāles jautājums, uzdevums - tev ir jābūt labākam, nekā tu esi. Un reizē ar šo nostādni - tev jābūt labākam, nekā tu esi - arī uzmundrinājums - tu vari būt labāks, nekā tu esi. Un kāpēc. Tāpēc ka katrā cilvēkā ir milzīgas potences. Milzīgas, neizmantotas iespējas katrā cilvēkā. Un arī atbildība par šīm iespējām. Arī pretrunas paša cilvēka iekšienē."

\section{VĒRES}

Bauman, Z. (2006) Liquid Modernity. Cambridge : Polity Press.

Bauman, Z.; Donskis, L. (2013) Moral Blindness: The Loss of Sensivity in Liquid Modernity. Cambridge : Polity Press.

Beitnere, D. (2003) Klātbūtne paša dzīvē: par sabiedrības morāles jautājumiem un nacionālās mutvārdu vēstures ekspedīcijās gūtajām atziṇām: saruna ar ētikas profesoru Augustu Miltu. Karogs, 9, $152-168$.

Beitnere, D. (2008) Dzīve ētikā un ētika dzīvē: intervija ar A. Miltu. Augusts Milts: patība un ètika. Rīga : RaKa, 77-101.

Buceniece, E. (2008) Domas sinerg̣ija: Augusta Milta filozofiskā proza. Augusts Milts: patība un ètika. Rīga : RaKa, 257-265.

Kierkegaard, S. (1983) Fear and Trembling: Repetition. Princeton : Princeton University Press.

Milts, A. (2001) Tautas izziṇa mutvārdu vēsturē. Zirnīte, M. (red.) Spogulis. Rīga : LU FSI, 33-39.

Milts, A. (2004) Saskarsmes ētika. Rīga : Zvaigzne.

Milts, A. (2008a) Dz̄̄ves apjēgsmes un ideālu meklējumos. Augusts Milts: patība un ētika. Rīga : RaKa, 10-21.

Milts, A. (2008b) Esejas un miniatūras. Augusts Milts: pat̄̄ba un ètika. Rīga : RaKa, 22-34. 